"The preparation of the labor relations landscape of South Africa (1994-2008): an environmental perspective for sustainable development"

\begin{tabular}{|c|c|c|}
\hline AUTHORS & \multicolumn{2}{|l|}{ Braam (AA) Rust } \\
\hline ARTICLE INFO & \multicolumn{2}{|c|}{$\begin{array}{l}\text { Braam (AA) Rust (2017). The preparation of the labor relations landscape of } \\
\text { South Africa (1994-2008): an environmental perspective for sustainable } \\
\text { development . Environmental Economics, } 8(1), 93-102 \text {. } \\
\text { doi:10.21511/ee.08(1).2017.10 }\end{array}$} \\
\hline DOI & \multicolumn{2}{|c|}{ http://dx.doi.org/10.21511/ee.08(1).2017.10 } \\
\hline RELEASED ON & \multicolumn{2}{|l|}{ Wednesday, 12 April 2017} \\
\hline & \multicolumn{2}{|l|}{ (cc) EY-NC } \\
\hline LICENSE & \multicolumn{2}{|c|}{$\begin{array}{l}\text { This work is licensed under a Creative Commons Attribution-NonCommercial } 4.0 \\
\text { International License }\end{array}$} \\
\hline JOURNAL & \multicolumn{2}{|l|}{ "Environmental Economics" } \\
\hline ISSN PRINT & \multicolumn{2}{|l|}{$1998-6041$} \\
\hline ISSN ONLINE & \multicolumn{2}{|l|}{$1998-605 X$} \\
\hline PUBLISHER & \multicolumn{2}{|c|}{ LLC "Consulting Publishing Company "Business Perspectives" } \\
\hline FOUNDER & \multicolumn{2}{|c|}{ LLC "Consulting Publishing Company "Business Perspectives" } \\
\hline \multirow[b]{2}{*}{ NUMBER OF REFERENCES } & & ニニニ \\
\hline & NUMBER OF FIGURES & NUMBER OF TABLES \\
\hline 20 & 0 & 1 \\
\hline
\end{tabular}

(C) The author(s) 2023. This publication is an open access article. 


\title{
The preparation of the labor relations landscape of South Africa (1994-2008): an environmental perspective for sustainable development
}

\begin{abstract}
This paper undertakes a review of the literature that examines the highlights and changes in specific external environmental factors (Ecology, Economy, Politics, Legislation and legal structures, and Society), between1994 and 2008 in South Africa, with the aim to ascertain how these factors affect the day-to-day labour relations in the workplace and add to sustainable development. These factors form the landscape for labour relations. Changes to them have consequences on the quality of labour relations, that is, inter alia, the frequency, and intensity of conflicts, disputes, demands and industrial actions. It is also evident that with its power and through the political system, the South African trade union was enhanced to shape the labour relations landscape. Labour laws were particularly designed to be worker friendly and to ensure that trade unions could use a fair collective bargaining system to spread the wealth of the mining industry, agriculture and other industries more evenly. Also, because of the alliance that exists between Labour and the ruling party (ANC), the economy was influenced so that economic policies could to a certain extent guide and steer economic growth, unemployment, inflation, interest rates and exchange rates. Trade unions were instruments in ensuring that formal changes in laws and policies did, in fact, reach and positively impact families and households within the social environment. Lastly, trade unions were the most effective instrument for heralding change within South Africa in the environmental fields of ecology, economy, politics, legislation and legal structures, as well as within society. Furthermore, these fields have interchangeably affected the labour relations landscape thereby indelibly shaping it between 1994 and 2008.
\end{abstract}

Keywords: environmental changes, sustainable development, labour relations, legislation and legal structures, ecology, economy, society, politics, landscape of labour relations.

JEL Classification: J50, J51, O44, Q01.

\section{Introduction}

Between 1994 and 2008, South Africa prepared its environment (economically, socially, legally, politically and also ecologically) to ensure sustainable development in specifically its labor relations and to make sure that it would run smoothly. Hard work was invested in this phase so as to create an environment that was at least stable on the labor front. The new legislation, specifically formulated to address labor aspects, was designed and accepted. In addition, new machinery (CCMA, Nedlac) was launched to assist with labor peace. Furthermore, this period allowed for the role players (labor, employers, government) enough time to settle into and negotiate the new systems. Also, the environmental factors were given enough time to reveal their specific cycles so that the role-players could implement the necessary changes for sustainable development and survival purposes.

Nevertheless, the period between 1994 and 2008 is known for its environmental changes in terms

\footnotetext{
(c) Braam (AA) Rust, 2017.

Braam (AA) Rust, Ed. Tech, B. Ed, M.Com., Ph.D., Senior Lecturer, Faculty of Business, Cape Peninsula University of Technology, South Africa.

This is an Open Access article, distributed under the terms of the Creative Commons Attribution-NonCommercial 4.0 International license, which permits re-use, distribution, and reproduction, provided the materials aren't used for commercial purposes and the original work is properly cited.
}

of employer-employee relationships: these included new designs for managing labor relations; new workplace rules; the beginning of transformation for the disadvantaged; the end of the previous political regime and the emergence of new political alignments; excitement and high expectations amongst the disadvantaged for a better future; businessmen confronted by new markets and opportunities, but also challenges; as well as politicians were eager to show that they had the ability to manage the country.

\section{Research question}

What were the outstanding environmental aspects of the SA labor relations landscape between 1994 and 2008 that most prominently influenced the labor relations of both that era and the next one?

\section{Objective of the study}

This study aims to highlight specific external environmental factors that had affected day-to-day labor relations in the workplace and helped to shape the SA labor relations landscape for sustainable development between 1994 and 2008, and thereafter. Retrospectively, specifically the environmental changes to the landscape, have consequences on the quality of labor relations. Therefore, workplace decisions should be aligned with the environmental forces to ensure organizational success. Because the effect and 
interplay of all of these factors were vast, only some were focused upon by way of illustration. Consequently, this research focuses only on the following environmental domains (during the period between 1994 and 2008), which are namely Ecology, Economy, Politics, Legislation and legal structures, and Society.

\section{Research approach and methodology}

This paper describes a specific era in the South African history (1994-2008). Therefore, it is descriptive in nature. Zikmund, Babin, Carr and Griffin (2013, p. 53) argue that this type of research describes the characteristics of the environment. It attempts to paint a picture of a given situation or era. The method used can also be described as a form of historical research/analysis (Quinlan, Babin, Carr, Griffin and Zikmund, 2015, p. 147; Maree, 2007). While it explores and analyzes the history of some phenomenon, it also forms part of empirical research, where existing text data are analyzed (Mouton, 2005, p. 57).

The study critically reviews secondary sources as a data collection method. It is literature that has already been published (Quinlan et al., 2015, p. 53). A variety of reasons exists for the use of this method of data collection. Considering the covert nature of labor relations in South Africa, due to political infighting and intimidation, access to primary data through interviews, is difficult. While acknowledging the missing enrichment that such data could have brought to this study, the use of secondary data facilitates a wide range of interpretive practices to give a better understanding of the subject matter (Quinlan et al., 2015, p. 54). Nonetheless, in general, the secondary data have its own limitations, which may include the danger of out-of-context interpretation, due to a lack of suitability and the relevance of the collected data for the purposes of this project. This is because certain data may have been collected by others with a different focus, as well as the difficulty in seeing the weak points of such data or the information used (Mouton, 2005, p. 90). However, the critical review of a wide range of sources in this study is particularly geared towards addressing such a lapse (De Vos, Strydom, Fouche, and Delport, 2014, p. 135).

\section{The meaning of the 'labor relations landscape': an environmental orientation and perspective}

The market economy is about survival, financial success, efficiency, and effectiveness. The ability to pass these tests depends on the ability to adapt to environmental changes to secure sustainable development. Labor relations and its dynamics is also part of the life of the enterprise, but more so, because it interplays strongly with the broader environment. Kochan $(1980$, p. 36), one of the first philosophers of labor relations, says that laborrelations have always been analyzed as an 'open system' - it means that labor relations must adapt to changing external conditions. Nel, Kirsten, Swanepoel, and Poisat (2012, p. 22) argue that labor relations are dynamic and are heavily influenced by, and, in turn, have an influence on other subsystems of society. For example, the internal environment of each organization refers to the specific characteristics of the organization - how well the internal organization will fit in and adapt to the external environment, the more survival and success is ensured. The external environment provides the opportunities, incentives and constraints on the parties. In brief, because the environment is an external one and somewhat fixed, the parties, therefore, have to adapt to it.

Important reasons exist to study the environment, because it largely determines the process and outcomes of collective bargaining. For instance much of the conflict in the employment relationship has its origins in the external environment of the organization (Grosset and Venter, 1998, p. 10). The labor is drawn from the society, and those factors which have an influence on society/environment will also impact the organization; survival and success of the organization is largely dependent on its monitoring of this environment and determining how each variable impacts on the various facets of the organization; and the environment factors are separate, they are also interdependent, and changes in one set of factors can cause related changes in a second set.

The dimensions of the ecology, economy, politics, legislation and legal structures, and society are essentially the main external environment factors.

\section{Environmental situation between 1994 and 2008}

After the first SA democratic elections in 1994, there was a clear need for radical change in South Africa's socioeconomic and political order (Ferreira, 2005). After 1994, a new history was written with a new government whose aim was to democratize and transform the country to the level, where the disadvantaged were included in decision-making positions.

2.1. Ecology. Although South Africa is seen as a developing country and has characteristics of a first and third world, it is in many ways welldeveloped and self-sustainable. Natural resources, 
like minerals, are mainly exported and machinery for production purposes imported. The country is fairly dry, but has a moderate climate and is, therefore, suitable for farming. Industries include mining (SA is the world's largest producer of platinum, gold, and chromium), automobile assembly, metal working, machinery, textiles, iron and steel, chemicals, fertilizer, food stuffs and commercial ship repair (Central intelligence Agency, 2015; Barry, 2013).

Although the positioning of the country is not ideal in terms of the big international markets (such as Western Europe, East Asia, and Northern America), modern technology ensures that agricultural products can quickly reach markets. Furthermore, South Africa has a well-developed infrastructure in terms of commerce, health, and education.

The wealth of the nation has, since the late nineteenth century, been built on minerals (Central Intelligence Agency, 2015). Harvey (2013, p. 6) maintains that mining still constitutes up to one-fifth of the South African economy, and constitutes more than half of all the country's export earnings and provides employment to more than 1.3 million people. The value of South Africa's mineral resource wealth stands at $\$ 2.5$ trillion, the largest in the world (Russia is second with a mere \$1.6 trillion).

Despite this remarkable fact industry has stagnated in terms of its contribution to GDP during the longest economic upswing from the early 1990 s to 2008 . Further, South Africa's rate of new investment growth is the lowest of any significant mining industry in the world. Goldberg and Wilkinson (2013) maintain that this is because of an investor-unfriendly political environment. The mining industry is not performing ideally (Harvey, 2013, p. 7). One reason is that minerals are exhaustible. Mining has been done commercially since the late 1800s; the quality of ore is decreasing, and it becomes increasingly difficult and expensive to access. Also, government policy and the political context in which miners operate is increasingly uncertain and complex. Nationalizing of the industry is an ongoing debate among politicians. This uncertainty is partly the reason for South Africa's poor mining performance during a global commodity boom. Then, also, labor market inefficiency, corruption, and infrastructure are other constraints that are taken as the other key explanatory variables. Harvey (2013, p. 9) argues that the decline in the labor market efficiency, in particular between 2002 and 2007, appears to be strongly associated with the deterioration of the attractiveness of the mining industry as a potential investment.

Agriculture is another industry under pressure and burdened with uncertainty (De Wet, 2015; Mbatha, 2015; Greenberg, 2015). Many land claims are currently awaiting processing. Another factor is the redistribution of land (National Treasury, 2010). Currently, the industry can still feed the nation, but, examining previous examples of land redistribution, fears exist that the new owners don't have the capacity (Kahn, 2007; Pepeteka, 2013). Furthermore, the laborers claim to be included in the ownership thereof. Also, farmers are not subsidized by the government, as it is done by European and North American farmers (Kahn, 2007; Pepeteka, 2013).

2.2. Economic environment. South Africa's economy, ranked as upper-middle income by the World Bank is currently one of the largest economies on the African continent. Historically, South Africa's economy was primarily built on primary and secondary industries, such as mining and manufacturing, but in recent decades, and in line with global developments, growth has shifted to the tertiary industries. Presently, industries that contribute to the economy include finance, real estate and business services; manufacturing; also wholesale and retail trade. It is known as an emerging market with an abundant supply of natural resources; well-developed financial, legal, communications, energy, and transport sectors; and a stock exchange that is Africa's largest and among the top 20 in the world. Even though the country's modern infrastructure supports a relatively efficient distribution of goods to major urban centers throughout the region, unstable electricity supplies retard growth. Economic growth went through its normal cycle, but was stable at $3-4 \%$. Unemployment, poverty, and inequality - among the highest in the world remain a challenge. Official unemployment stabilizes at around 23\%; and runs significantly higher among black youths (Statistics SA, 2015; Central Intelligence Agency, 2015).

By examining the South African economy between 1994 and 2007, the economic indicators reveal that it experienced neither dramatically low nor dramatically high figures, also that it performed normally, as would be expected from any economy (Jones, 2013). The figures below indicate this. 
Table 1. Economic indicators of South Africa (1994-2009)

\begin{tabular}{|l|c|c|c|c|}
\hline Year & $\begin{array}{c}\text { Economic growth rate } \\
(\text { GDP })\end{array}$ & Inflation & Unemployment & $\begin{array}{c}\text { Rand/Dollar } \\
\text { exchange rate } \\
\text { average for the year }\end{array}$ \\
\hline 1994 & 3.2 & 9.9 & 20 & 3.54 \\
\hline 1995 & 3.1 & 9.7 & 16.9 & 3.62 \\
\hline 1996 & 4.3 & 7.3 & 21 & 4.29 \\
\hline 1997 & 2.6 & 8.6 & 22.9 & 4.61 \\
\hline 1998 & 0.5 & 6.9 & 25 & 5.53 \\
\hline 1999 & 2.4 & 5.3 & 25.4 & 6.11 \\
\hline 2000 & 4.2 & 5.3 & 26.7 & 6.95 \\
\hline 2001 & 2.7 & 5.7 & 25.4 & 8.61 \\
\hline 2002 & 3.6 & 9.5 & 27.2 & 10.49 \\
\hline 2003 & 2.8 & 5.8 & 27.1 & 7.54 \\
\hline 2004 & 3.7 & 4.8 & 24.7 & 6.43 \\
\hline 2005 & 5.3 & 5.1 & 23.8 & 6.37 \\
\hline 2006 & 5.6 & 5 & 22.6 & 7.77 \\
\hline 2007 & 5.5 & 6.2 & 22.3 & 8.27 \\
\hline 2008 & 3.6 & 10.4 & 22.7 & 8.41 \\
\hline 2009 & -1.5 & 7.3 & 23.7 & 7.32 \\
\hline 2010 & 3.1 & 3.4 & 23.3 & 7.26 \\
\hline 2011 & 3.5 & 6.4 & 24.9 & 8.21 \\
\hline 2012 & 2.5 & 5.7 & 22.7 & 9.65 \\
\hline 2013 & 2.8 & 5.3 & 24.9 & 10.85 \\
\hline 2014 & 1.5 & 5.3 & 25 & \\
\hline
\end{tabular}

Sources: Inflation.eu (2015); Statistics South Africa (2014), P0441; African Economic Outlook (2015); BusinessTech (2015); South African Reserve Bank (2014); Bloomberg Markets (2015).

After 1994, South African economic policies focused on maintaining and growing the economy, as well as controlling inflation; however, the country faces structural constraints that also limit economic growth; these include skills shortages, declining global competitiveness, and frequent work stoppages due to strike action.

What stands out from these figures is the high unemployment rate of around 25\% (SAinfo Reporter, 2014). Employment is naturally linked to economic growth, and without dramatic changes in the economic growth, not much will happen with unemployment (SAinfo Reporter, 2014; World Bank, 2015). And, economic growth depends largely on new investments (Gaspard, 2014). The increase in violent strikes from 2005 is also not favoring new investment (Gaspard, 2014; Gentle, 2012; Jones, 2013; SAinfo Reporter, 2014; Donnelly, 2014).

Business, Government, and Labor are all parties that have a responsibility to build and protect the economy and sustainable development (Gaspard, 2014). In South Africa, the government has played a central and influential role over the centuries in the economy. Much is, therefore, expected from the government to ensure that the economy is kept on track. However, the potential of mismanagement due to greediness and a hunger for power remains a reality.

Since the start of the democracy (1994), the government had challenges with supporting its own ideologies
(Donnelly, 2014). Prior to the new dispensation in 1994, ANC (current ruling party) members supported socialism as an economic system (Alexander, 2014; Duncan, 2014; Sklar, 2008; Callinicos, 1996). When the office was taken charge of, surprisingly the market principle (capitalism) was chosen. The international world played an important role in this decision (Alexander, 2014). Today the government still supports its original choice (capitalism), but interference into the economy and more participation in the market as a supplier of goods and services indicates that the government has not yet fully distanced itself from its socialistic ideas (Duncan, 2014; Sklar, 2008). For instance, the nationalization of the mining industry is something that often rears its head (Donnelly, 2014).

Another challenge is that the ruling political party (ANC) has since 1994 found it difficult to manage its previously close relationship with Cosatu, the biggest federation of trade unions comprising over 2 million members (Donnelly, 2014). This relationship, plus the SA Communist Party, was always an alliance (Duncan, 2014; Du Plessis, 2014; SAinfo Reporter, 2014). During elections, the government experienced that these two alliance partners supported the government. However, this came at a price. The government had to design legislation, suitable for the worker and trade unions in labor (Du Plessis, 2014). Further, to design economic policies that were not favoring laborers was difficult for the government (Alexander, 2014). 
Another problem the government had to struggle with since 1994 is the acceptance of public sector workers joining trade unions and the rapid growth of these trade unions in terms of numbers (Rautenbach, 2014; Donnelly, 2014). Rautenbach (2014) says that between 2000 and 2012 a quiet, insidious revolution took place in South Africa, in that government employment rose by approximately $46 \%$, while private sector employment barely increased. The ratio of private to government workers changed from $5.5 / 1$ to $3.9 / 1$ over this period. Whilst private sector employment stagnated, government employment increased by 850000 jobs. The challenge is that most of the public sector trade unions are also members of Cosatu. This situation became very difficult to manage. That was because the public sector trade unions were so powerful that they and not government made many decisions that were not to the employer's advantage (Di Paola, 2012; Rautenbach, 2014; Duncan, 2014). Thus, a situation was created that decision-making was actually left to, or strongly influenced by Cosatu (Donnelly, 2014).

2.3. Political expectations. The newly elected government of 1994 was confronted by great expectations among the electorate (Ferreira, 2005, p. 197). This government, led by the African National Congress (ANC), had by far the majority in the election. Workers expected the government to rapidly overturn the legacy of apartheid. Addressing the massive socio-political and economic imbalances between the people of South Africa was high on supporters' wish lists. There were expectations around the creation of jobs, better and new investments, improved education, training and health services.

COSATU, the African National Congress (ANC) the ruling political party - and the South African Communist Party were all part of an alliance called the Tripartite Alliance (Anstey, 2013, p. 137). Through this alliance trade unionists became politicians in the new dispensation, serving the interests of all stakeholders, especially labor in labor relations.

The most important implication of the new political dispensation for labor relations sustainable development in South Africa was the emphasis on worker rights, workplace democracy, affirmative action, industrial restructuring and the restructuring of education and training. After 1994, labor relations in South Africa were conducted in a fundamentally new context. The new government (post-1994) aimed to transform their previous employment relationship from an adversarial relationship, where employers and employees tend to be constantly in conflict, to a more cooperative, democratic relationship in which employees and employers could work together as partners to achieve common objectives (Ferreira, 2005, p. 209). Labor (in alliance with the ruling party, the ANC) has been a primary vehicle in engineering this change, through widespread socioeconomic and political renewal in the workplace. The labor legislation framework has been restructured over the last decade. Government intervention was required to reform the workplace to meet the socio-political needs of the majority of South Africans, who were previously excluded (Anstey, 2013). This change was brought about by major changes in labor legislation.

2.4. Legislation and legal structures. South Africa's labor legislation framework, promulgated between 1994 and 2009, is regarded as one of the most comprehensive in the world (Ferreira, 2005, p. 198). It has done much to redress the imbalances of the past. The degree of intervention in the labor market creates, on the one hand, a great deal of inflexibility and rigidity in the employment relationship, particularly among small to medium enterprises. This integrated system of rights and protection provides, on the other hand, for the facilitation of a more harmonious and equitable relationship. After the 1994 elections, it was crucial to develop the economy in order to increase employment and redistribute wealth. In labor, a spirit of industrial democracy had to be created and production and labor peace encouraged through greater understanding and joint decision-making (Ferreira, 2005, p. 198). This was done under the umbrella of the Constitution of the Republic of South Africa Act (108/1996).

2.4.1. Legislation. Legislation provides guidance, order, respect and protection for society as well as to provide structure to systems. Therefore, for the new democratic South Africa, the following new laws were promulgated for that purpose (SAinfo Reporter, 2014).

Labor Relations Act (6/1995): The Act is designed to promote democracy in the workplace (SAinfo Reporter, 2014; Anstey (2013, p. 137). It provides for collective bargaining as the most acceptable means of resolving disputes of mutual interest and encourages and provides the means to reach an agreement.

Basic Conditions of Employment Act (75/1997): This act aims to advance economic development and social justice by giving effect to and regulating fair labor practices. It includes establishing and enforcing, as well as regulating the variation of basic conditions of employment (SAinfo Reporter, 2014). 
Employment Equity Act (55/1998): The purpose of this act is to achieve equity in the workplace by promoting equal opportunity and fair treatment in employment through the elimination of unfair discrimination, as well as to implement affirmative action to redress past inequalities in the workplace by promoting the employment and promotion of individuals from previously disadvantaged background (SAinfo Reporter, 2014).

Skills Development Act (97/1998): This act aims to develop the skills of the South African workforce (SAinfo Reporter, 2014).

\subsubsection{Structures/machinery/institutions. Anstey (2013,} p. 135) says some structures/institutions were necessary as vehicles for dialogue, and as checks and balances to ensure South Africa's democracy had "legs".

National Economic Development and Labour Council (Act 35 of 1994): Nedlac's objectives are to (SAinfo Reporter, 2014) to strive to promote the goals of economic growth, to participate in economic decision-making and social equity; to seek to reach consensus and conclude agreements pertaining to social and economic policy; and to consider all proposed labor legislation relating to labor market policy before it is introduced in Parliament.

This was the first attempt towards community corporatism in South Africa, where employers and union representatives voluntarily took part in the government's drive towards empowerment.

Commission for Conciliation, Mediation and Arbitration (CCMA): Since its inception in 1996, the CCMA has dealt with thousands of cases. The CCMA provides a sophisticated dispute resolution service (SAinfo Reporter. 2014). It offers easy access to dispute resolution (Anstey, 2013, p. 137). The majority of disputes referred to the CCMA relate to individual dismissal and are settled at the conciliation stage.

\section{Other: Labor Court and Labor Appeal Court.}

2.5. Social environment. Introduction: The society that people live in has a direct influence on the wellbeing of them as employees. This well-being affects the mood, motivation, and fitness for work of the individual. And, this is carried into the workplace and has an effect on the output, productivity, and profitability of organizations. Discord in one environment in the society will impact on performance in the other (workplace) and collective bargaining. Each of these impacts the labor relationship. Some of the dimensions affecting society are:
Poverty: This is a key development challenge in social, economic and political terms, not only in South Africa, but also throughout the developing world. In post-apartheid South Africa, fighting the legacy of poverty and under-development has always been a central theme of Government.

Unemployment: South Africa has a high unemployment rate of $25 \%$, compared to an average of $11 \%$ for upper middle-income countries. Onethird of South Africa's labor force is either out of work or not looking for jobs, a challenge that has arisen because of the low rate of job creation (Statistics South Africa, 2015; Central Intelligence Agency, 2015).

Healthcare: Expenditure on healthcare is $8.9 \%$ of GDP. This gives the country a $42^{\text {nd }}$ place in comparison to the world. The biggest challenge is HIV/AIDS. People living with HIV/AIDS are $6,274,100$ (2013). This means that the country, in comparison to the rest of the world, has the second highest infection rate globally (Central Intelligence Agency, 2015).

Transport: There are approximately 3.9 million public transport commuters. Despite that the aim of the Department of Transport is to lead in the provision of an integrated, sustainable, reliable and safe transport system - via the planning, developing, coordinating, promoting and implementation of transport policies and strategies - the public transport industry is challenged by poor transport networks, poor service, the poor condition of vehicles and trains, also a disregard for passengers; furthermore it is not cheap, even though it is meant to serve poor people, most of whom are unemployed (Mzansi Empowerment Network, 2015; Oxford, 2013; Arrive Alive, 2009). A further challenge is poor quality and unreliable buses, fraudulent bus operators who were awarded contracts and subsidies and neglect their responsibility to maintain roadworthy vehicles.

Housing: In 1994, the housing backlog was estimated to be 1.2 million homes for the black population. In the late 1990s, there was an explosive growth of shacks and shanty towns surrounding South Africa's major urban areas. Cities could not plan effectively to cater for the needs of these people and shelters were built where ever possible (Learn xtra live, 2014). Therefore, most of the townships and squatter settlements lack the basic infrastructure and services of water, sewage, and electricity.

Education/schooling: The quality of education is pivotal for the production of human capital in the country (Legotlo, 2014). South Africa still faces the 
reality of two different education systems, a dysfunctional schooling system (75\%) and a functional schooling system (25\%), which are miles apart in their respective performance (Bhoola, 2002). Despite the high spending (20\% of total government expenditure, that is $6.2 \%$ of GDP on education, of which $78 \%$ goes to teacher salaries (Central Intelligence Agency, 2015) and many interventions, which were made by the government over the past twenty years, the system remains virtually unchanged (Spaull, 2012).

South Africa's education system was ranked 133rd out of 142 countries in the world by the World Economic Forum (Spaull, 2012). Dirks (2013) argues that the South African education system is grossly inefficient, severely underperforming and egregiously unfair. Spaull (2013) says it has the worst education system of all middle-income countries that participate in cross-national assessments of educational achievement; it performs worse than many low-income African countries; most South African pupils cannot read, write and compute at grade-appropriate levels, with large proportions being functionally illiterate and innumerate; of 100 pupils that start school, only 50 will make it to Grade 12, 40 will pass, and only 12 will qualify for university.

Municipal services: Due to rapid urbanization and unplanned settlements, it has made it difficult to provide services to all the people. Approximately $11 \%$ of South Africans live in informal settlements (Learn xtra live, 2014). The increasing demand for services and infrastructure is greatest in the informal settlements and the transition zone, and this is where poverty is also the greatest challenge. Basic services include housing, healthcare facilities, educational facilities, sanitation, clean drinking water, and electricity. Infrastructure includes roads, power lines and communication networks (Molinyane, 2012; World Bank, 2011).

\section{Conclusions}

It is clear from the foregoing that changes in specific external environmental factors (Ecology, Economy, Politics, Legislation and legal structures, and Society), between 1994 and 2008, have had an effect on sustainable development and the day-to-day labor relations in the workplace. They form the landscape for labor relations and changes to them have consequences on the quality of labor relations - the frequency and intensity of conflicts, disputes, demands and industrial actions.

After 1994, there was a clear need for radical change in South Africa's socioeconomic and political order
(Ferreira, 2005). The new government introduced significant institutional transformation and new policies in line with the Constitution. However, a situation was created where certain workers ended up into advantaged positions and other worker groups remained in the worker class group. Frustration levels were raised and it began to spill over in community unrest and protests.

On the domain of the ecology, South Africa is blessed with a well-developed infrastructure, land and climate suitable for farming and tourism, and a wealth of minerals. Although the mining industry has large potential, the industry stagnated in terms of its contribution to GDP. The rate of new investment growth is the lowest of any significant mining industry in the world (Goldberg and Wilkinson, 2013; Harvey, 2013, p. 7). This indicates the industry as a risky environment for investors and sustainability.

Agriculture is another industry under pressure and burdened with uncertainty and negativity in terms of sustainability (Mbatha, 2015; De Wet, 2015; Pepeteka, 2013; National Treasury, 2010). Laborers insist on being incorporated as part of the ownership - another issue that categorizes the farming industry as an uneasy environment for investors. Job creation competed with mechanization and atomization which was not what trade unions wanted.

The economic landscape has its own challenges for labor relations and sustainability. The country is known as an emerging market with an abundant supply of natural resources; well-developed financial, legal, communications, energy, and transport sectors (Statistics SA, 2015; Central Intelligence Agency, 2015). Economic growth went through its normal cycle, but was stable at 3-4\%. Unemployment, poverty, and inequality - among the highest in the world - remain a challenge. Official unemployment stabilizes at around 23\%; and runs significantly higher among black youth (Statistics South Africa, 2014; African Economic Outlook 2015; BusinessTech 2015; South African Reserve Bank, 2014; Bloomberg Markets, 2015). A positive economic growth rate with a high, but stable unemployment rate is not good news for trade unions. This indicates that the market is not willing to employ workers - potential trade union members are lost and trade union power stagnated. The inflation rate went from $9 \%$ to $6 \%$. If a relatively high inflation rate indicates an active economy with high demand, this, then, is further bad news for trade unions.

The exchange rate increased from R3.50 to R8.00 for \$1 during 1994 to 2008 (Bloomberg Markets 2015). This was both good and bad news for the trade unions and for sustainable imports and exports. Employers in the export market welcome a 
poorer exchange rate - and trade unions' power, then, increases. The opposite is true in the import market. With the opening of international markets after 1994, both exports and imports definitely increased with mixed results on trade unions (Central Intelligence Agency, 2015).

Notwithstanding the challenges that trade unions have faced regarding changes in the economy, they have had a solid companion in the ruling political party (ANC). The South African government has played a central role over the centuries in influencing the economy. Sometimes the market economy is merciless with poor productivity and ineffectiveness - something trade unions in South Africa are often guilty of. However, the Government had to ensure that labor and trade unions were protected from the market (Du Plessis, 2014, Alexander, 2014; Duncan, 2014; Sklar, 2008).

While the acceptance of the public sector worker in the labor relations arena has worked in favor of the totality of labor power in the country, it has, however, created headaches for the role of the state as the employer and a sustainable economy (Rautenbach, 2014; Donnelly, 2014; Di Paola, 2012; Duncan, 2014).

In the legislation and legal structures domain, namely the labor legislation framework of South Africa that was promulgated between 1994 and 2009, calmness and stability were introduced into the South African labor relations landscape. It leveled the playing field; all of the role players' efforts brought fairness to the workplace. This framework is regarded as one of the most comprehensive in the world (Ferreira, 2005, p. 198). Anstey (2013, p. 137) further says a labor-friendly legislation was negotiated among the social partners (government, business, and labor).

The new labor laws provided employees more recognition and workplace rights. Trade unions also had more power. This led to new expectations and sometimes uncertainty in a sustainable environment: employers had to make serious changes to their policies, processes, and procedures so as to be compliant with the laws. This era is known as a settlement stage for labor relations, because many things were new and challenged all the participating parties. The number of disputes and industrial actions were lower in the first four years after 1994 and have steadily increased, but they also fluctuate yearly - workdays lost due to strikes, $1990=4$ million; $1994=3.7$ million; $1995=1.6$ million; $1997=0.7$ million; and a sharp increase in $1999=$ 3.2 million (Ferreira, 2005, p. 209).
The Structures/machinery/institutions [(National Economic Development and labor Council (Act 35 of 1994); also the Commission for Conciliation, Mediation and Arbitration (CCMA] have played a role in keeping the field stable (Anstey, 2013, p. 135).

There was pressure on the newly elected government in 1994 due to the enormous political expectations from the majority of the electorate (Ferreira, 2005, p. 197). The majority, who had elected the new government into power, expected it to rapidly overturn the legacies of the apartheid system. There were expectations around the creation of jobs, better and new investments, improved education, training and health services. The Tripartite Alliance [COSATU, the African National Congress (ANC) - the ruling political party - and the South African Communist Party] made it their goal in the new dispensation to serve the interests of all stakeholders, especially labor in labor. Through this move, trade unions received a direct say in decision-making in government decisions. The power of the employer made a room for more power to the trade unions, which was underpinned by government legislation and policies (Anstey, 2013).

The domain most likely affecting the labor relations landscape the most was the social environment from where the workforce originates. The South African context of divided communities and a poor workforce from shanty townships detracts from the well-being, mood, and motivation of workers in the workplace. Additional to that are the following: a heterogeneous society in terms of racial, cultural and linguistic diversity; poor areas fighting the legacy of poverty and under-development; high density living conditions in the townships of bigger towns and cities due an explosive growth of shacks and shantytowns in urban areas, which results in free electricity and water services and non-existent rents or mortgages; a health care state under pressure due to the vast challenge of HIV/AIDS; the daily 2.5 million taxi commuters account for over 63 percent of public transport work trips; a dysfunctional schooling system for the majority $(75 \%)$ in the poor areas, as well as a lack of municipal services due to rapid urbanization and unplanned settlements. A social environment with the above characteristics provides enough reasons fortrade unions to demand more from employers such as the delivery of functioning and efficient services.

In conclusion, it is evident that with the environmental changes, the power of the South African trade unions was enhanced via the political 
system and, thus, was able to shape the labor relations landscape and also sustainable development. Labor laws were in particular designed to be worker friendly and to ensure that trade unions could use a fair collective bargaining system to more evenly and fairly distribute the wealth of the mining industry, agriculture and other industries. Also, due to the alliance that labor has with the ruling party (ANC), the economy could be influenced so that economic policies would to a certain extent guide and steer economic growth, unemployment, inflation, interest rates and exchanged rates. Furthermore, the status quo existing in the social environment could, via the trade unions, be changed and improved. Apart from all the other role-players in labor relations, the trade unions in particular were ideally positioned and had the most effective management structure so as to herald change in South Africa's ecology, economy, politics, legislation and legal structures, and society. This was especially the case as - interchangeably these fields had the power to positively affect and change the labor relations landscape, thus making the rewriting the narrative that unfolded between 1994 and 2008 possible.

\section{References}

1. African Economic Outlook. (2015). African development Bank Group. Available at: http://www.africaneconomicoutlook.org/en/statistics/table-2-real-gdp-growth-rates-2003-2013/ Accessed on 6 Sept 2015.

2. Alexander, N. (2014). 100 years of the African National Congress, South African history online. Available at: http://www.sahistory.org.za. Accessed on 8 Sept 2015.

3. Anstey, M. (2013). Marikana - and the push for a new South African pact, South African Journal of Labor Relations, 37(2), pp. 133-145.

4. Arrive alive 2009. (2009). Overview of Public Transport in South Africa. Available at: https://www.arrivealive.co.za/Public-Transport. Accessed on 11 September 2015

5. Barry, G. (2013). Deep ecology and technology for global ecological sustainability, EcoInternet, October 20.

6. Bhoola, U. (2002). National Labor Law Profile: South Africa, Promoting jobs, protecting people, International Labor Organization.

7. Bloomberg Markets. (2015). Bloomberg News, April. www.bloomberg.com/markets, (8 Sept 2015).

8. BusinessTech. (2015). South Africa unemployment: $1994-2015$. Available at: http://businesstech.co.za/news/international/77737/south-africa-unemployment-1994-2015/ Accessed on 6 Sept 2015.

9. Callinicos, A. (1996). South Africa after apartheid, International socialism, Quarterly journal of the Socialist Workers Party (Britain), Issue 70, March.

10. Central intelligence Agency. (2015). South Africa: The World Factbook. Available at: https://www.cia.gov/library/publications/the-world-factbook/.../sf.html. Accessed on 6 Sept 2015.

11. De Vos, A.S., Strydom, H. Fouche, C.B., Delport, C.S.L. (2014). Research at grass roots: for the social sciences and human services professions, Fourth edition, Pretoria: Van Schaik Publishers.

12. De Wet, P. (2015). Farms lie fallow while leaders remain idle, Mail \& Guardian, 15 May.

13. Di Paola, M. (2012). The South African trade union movement: Vibrant, rich in history - and the challenges ahead, 29th World Congress of Public Services International. Durban.

14. Dirks, N. (2013).The challenges of South Africa's education system, Dreams to reality, September 3.

15. Donnelly, L. (2014). SA's economy depends on mining labour relations, says Manuel, Mail \& Guardian, 4 Feb.

16. Du Plessis, G. (201). New dawn for SA labour relations - old political alliances in tatters, businesses have stopped rolling over, Biznews. Available at: http://www.biznews.com/thought-leaders/2014/02/marikana-new-labourrelations-dispensation/ Accessed on 6 Sept 2015.

17. Duncan, J. (2014). The pro-capitalist media are ignoring the dawn of socialism in SA, Mail \& Guardian, 17 January.

18. Ferreira, G.M. (2005). Developments in labour relations in South Africa:Ten years of democracy (1994-2004), Politeia, 24(20), pp. 197-214.

19. Gaspard, P.H. (2014). US and South Africa: Facing Today's Challenges for Tomorrow's Opportunities. Speech of US Ambassador, University of South Africa, Pretoria, South Africa. February 20.

20. Gentle, L. (2012). South Africa after Marikana massacre: Strike wave and new workers' organizations challenge old compromises, South Africa Post, August. Available at: http://selim1404.wordpress.com/2012/11/28/southafrica-after-marikana-massacre-strike-wave-and-new-workers-organizations-challenge-old-compromises/ Accessed on 28 Nov 2012.

21. Goldberg, J. \& Wilkinson, G. (2013). What is the state of industrial relations in South Africa? HR Pulse: The knowledge hub for HR professionals, 21 January.

22. Greenberg, S. (2015). Why size matters for farmers, Mail \& Guardian, 13 March.

23. Grosset, M. and Venter, R. (1998). Labour relations in South Africa: A comprehensive guide for managers and practitioners, Johannesburg: Thomson publishing. 
24. Harvey, H. (2013). Marikana as a tipping point? The political economy of labour tensions in South Africa's mining industry and how best to resolve them. South African Institute of International Affairs, African perspectives, global insights. November.

25. Harvey, E. (2015). How the ANC brought Cosatu to its knees, Rand Daily Mail, April 30. Inflation.eu. (2015). Worldwide inflation data. Available at: http://www.inflation.eu/contact.aspx. Accessed on 6 Sept 2015.

26. Jones, G. (2013). What's wrong with SA's industrial relations? Financial Mail, February 21.

27. Kahn, N. (2007). Land and Agrarian Reform in South Africa. Policy: issues and actors, Centre for Policy Studies, 20(12), April, ISBN: 978-1-919708-87-4.

28. Kochan, T.A. (1980). Collective bargaining and industrial relations: from theory to policy and practice. Homewood: Richard D. Irwin, Inc.

29. Learn xtra live. (2014). Urban settlement issues. 4 June. Available at: http://learn.mindset.co.za/ sites/default/files/resourcelib/emshare-show-note-asset/LXL_Gr12Geography 17 Urban\%20Settlement\%20Issues_05June2014_61318.pdf. Accessed on 11 September 2015.

30. Legotlo, M.W. (2014). Challenges and issues facing the education system in South Africa, Africa Institute of South Africa (AISA), ISBN: 978-0-7983-0460-3.

31. Maree, K. (2007). First steps in research. Editor, Pretoria: Van Schaik Publishers.

32. Mbatha, N. (2015). Rushing land reform only slows it down, Mail \& Guardian, 7 August.

33. Molinyane, M.S. (2012). The nature and problems of metropolitan service delivery in South Africa, UJDigispace, Univerity of Johannesburg Library and information Centre. April.

34. Mouton, J. (2005). How to succeed in your master's and doctoral studies: a South African guide and resource book, Pretoria: Van Schaik Publishers.

35. Mzansi Empowerment Network. (2015). Public transport challenges and potential in South Africa. Available at: https://mzansiempowermentnetwork.wordpress.com/2011/08/30/public-transport-challenges-and-potential-insouth-africa/ Accessed on 6 Sept 2015.

36. National Treasury. (2010). Provincial budgets and expenditure review: 2010/11 - 2016/17, Ch9 Agriculture and Land. Available at: www.treasury.gov.za/.../09.\%20Chapter\%209\%20- \%20Agriculture\%20and\%20Land.pdf. Accessed on 6 Sept 2015.

37. Nel, P.S., Kirsten, M., Swanepoel, B.J. and Poisat, P. (2012). South African employment relations: theory and practice, Seventh edition. Pretoria: Van Schaik publishers.

38. Nomvalo, L. (2011). Improving service delivery in South African metropolitan municipalities, Deloitte Consulting, Augustus 4.

39. Oxford, T. (2013). The state of SA's public transport, Mail \& Guardian, 4 October.

40. Pepeteka, T. (2013). Reversing the Legacy of the 1913 Natives Land Act: Progress of Land Reform, Research Unit, Parliament of the Republic of South Africa, 27 May.

41. Quinlan, C., Babin, B.J., Carr, J.C., Griffin, M. and Zikmund, W.G. (2015). Business research methods, First edition, Hampshire, UK: South-Western, Cengage Learning.

42. Rautenbach, F. (2014). The more union members, the less job growth, South Africa can work,1 April.

43. SAinfo Reporter. (2013). Brand South Africa's information gateway to South Africa, 12 April.

44. SAinfo Reporter. (2014). Brand South Africa's information gateway to South Africa, 4 December.

45. Sklar, R.L. (2008). Beyond Capitalism and Socialism in Africa, The Journal of Modern African Studies, 26(01), pp. 1-21, March.

46. South African Reserve Bank. (2014). Monetary policy review, December. Available at: https://www.resbank.co.za/Lists/News\%20and\%20Publications/Attachments/6513/MPRDec2014.pdf._Accessed on 6 Sept 2015.

47. Spaull, N. (2012). South African education: unequal, inefficient and underperforming, College of Education, Unisa, July 18.

48. Spaull, N. (2013). South Africa's Education Crisis: The quality of education in South Africa 1994-2011, Report Commissioned by CDE (Centre for Development \& Enterprise), June.

49. Statistics South Africa. (2014). Statistical release P0441, November 25.

50. Statistics South Africa. (2015). Available at: http://www.statssa.gov.za/ Accessed on 6 Sept 2015.

51. World Bank. (2011). Accountability in Public Services in South Africa, Selected Issues Defining civil society. Available at: http://web.worldbank.org/WBSITE/EXTERNAL/TOPICS/CSO/0,,contentMDK:20101499 menu PK:244752 pagePK:220503 piPK:220476 theSitePK:228717,00.html. Accessed on 15 September 2015.

52. World Bank. (2015). South Africa Economic Update: Seizing the Window of Demographic Opportunity - Focus on Jobs and South Africa's Changing Demographics, analyzes and complex challenges. August 17. Available at: http://www.worldbank.org/en/country/southafrica/publication/south-africa-economic-update-jobs-changingdemographics. Accessed on 6 Sept 2015.

53. Zikmund, W.G., Babin, B.J., Carr, J.C. and Griffin, M. (2013). Business research methods, Ninth International Edition, Hampshire, UK: South-Western, Cengage Learning. 